\title{
Deoxyribonucleic Acid Base Composition of Bacterionema matruchotii
}

\author{
LAWRENCE R. PAGE and GEORGE N. KRYWOLAP \\ Department of Microbiology, University of Maryland School of Dentistry, Baltimore, Maryland 21201
}

\begin{abstract}
The thermal denaturation profiles $\left(T_{m}\right)$ of six strains of Bacterionema matruchotii were determined. The $\mathrm{mol} \% \mathrm{G}+\mathrm{C}$ of five of the strains ranged from 55.0 to 58.0 . The $\mathrm{mol} \% \mathrm{G}+\mathrm{C}$ of the strain referred to as streptococcal variant $\mathrm{S}_{1}$ fell short of this range (42.5), suggesting that it is substantially different from the others and perhaps improperly identified.
\end{abstract}

The phylogenetic relationships among oral filamentous microorganisms have not been completely resolved. For a number of years, certain oral, Gram-variable, filamentous, and rod-shaped bacteria have been variously classified as Leptotrichia, Leptothrix, and Rasmussenia. Gilmour et al. (4), after reviewing the morphological and biochemical status of these organisms, proposed that some of them be placed in one of two genera: Leptotrichia, family Lactobacillaceae; or Bacterionema, family Actinomycetaceae; with $L$. buccalis and $B$. matruchotii as the respective type species.

Due to the extreme cellular and colonial polymorphism of various strains of B. matruchotii and to the variability of their metabolic activities, we decided to investigate their deoxyribonucleic acid (DNA) base composition (guanine + cytosine $[\mathrm{G}+\mathrm{C}]$ content) and to compare the resulting values to those reported in the literature for the various species of the family Actinomycetaceae.

All strains of $B$. matruchotii used in the study were grown in brain heart infusion broth (Difco) supplemented with $0.2 \%$ yeast extract (Difco) for $48 \mathrm{~h}$ at $37 \mathrm{C}$. The cells were harvested and lysed, and the DNA was extracted by a method reported earlier (11).

Due to the high melting temperatures $\left(T_{m}\right)$ of DNA reported in the literature for the various species of the family Actinomycetaceae, phosphate-ethylenediaminetetraacetic acid (EDTA) buffer (ionic strength $=0.0225$ ) was used to solubilize the DNA instead of the usual saline citrate in order to lower the melting temperature $(3,10)$. This buffer system was tested with calf thymus DNA (sodium salt, type
V; Sigma), and the results obtained were found to be consistent with those reported in the literature.

To ensure consistency in buffer concentration, both calf thymus and $B$. matruchotii DNA were dialyzed in the same flask against the phosphate-EDTA buffer at $4 \mathrm{C}$. The thermal denaturation profiles were carried out by using the procedures of Mandel and Marmur (8) on a Gilford 2400 automatic recording spectrophotometer equipped with a model 2417 thermosensor and Haake model FJ constanttemperature circulator. Each thermal melt was carried out at least twice, and calf thymus DNA was used as an internal control for each run. The $\mathrm{mol} \% \mathrm{G}+\mathrm{C}$ values derived from the thermal denaturation profiles were also confirmed for one strain of $B$. matruchotii and calf thymus by determining the buoyant densities of their DNA in $\mathrm{CsCl}$ as described by Mandel et al. (9).

Table 1 summarizes the results obtained for the six strains of $B$. matruchotii. Note that five of the strains tested were closely related, the mol\% $\mathrm{G}+\mathrm{C}$ values ranging from 55 to 58 . However, the strain described by Strekfuss and Smith (12) as the streptococcal variant, $\mathrm{S}_{1}$, fell short of this range. This finding tends to support that of Gilmour and Turner (Int. Ass. Dent. Res. Abstr. No. 122, 1973) that the $S_{1}$ variant is probably a streptococcal contaminant. The mol\% $\mathrm{G}+\mathrm{C}$ of 42.5 obtained by us for this strain is very close to the $G+C$ values that have been reported for some of the oral streptococci (2).

Table 2 compares the $\mathrm{G}+\mathrm{C}$ contents of $B$. matruchotti strains with those that have been reported in the literature for various oral 
TABLE 1. Analysis of DNA from various strains of Bacterionema matruchotii

\begin{tabular}{l|c|c|c|c|c}
\hline \multicolumn{1}{c|}{ Strain $^{a}$} & $A_{260 / 280}$ & $T_{m}$ & Mol\% G+C & $\begin{array}{c}\text { Buoyant } \\
\text { densities }\end{array}$ & $\begin{array}{c}\text { Mol\% G+C from } \\
\text { buoyant densities }\end{array}$ \\
\hline ATCC 14265 & 1.90 & 92.2 & 56.4 & & \\
ATCC 14266 & 1.90 & 91.8 & 56.0 & & \\
WHB9A (rough) & 1.89 & 92.5 & 58.0 & 1.7143 & 55.4 \\
8 MG (smooth) & 1.87 & 91.6 & 55.5 & & \\
8 MG (rough) & 1.80 & 91.3 & 55.0 & & \\
S $_{1}$ & 1.97 & 86.7 & 42.5 & & \\
Control & & & & & \\
Calf thymus DNA & 1.90 & 86.5 & 42.5 & 1.7004 & 41.3 \\
\hline
\end{tabular}

${ }^{a}$ All strains except $S_{1}$ were kindly supplied by Marion N. Gilmour of the Eastman Dental Center, Rochester, N.Y. Strain $S_{1}$ was kindly supplied by W. N. Smith of the University of Texas Dental Science Institute, Houston, Tex.

TABLE 2. $G+C$ content of DNA of certain members of the family Actinomycetaceae

\begin{tabular}{|c|c|c|}
\hline Species & $\begin{array}{c}\mathrm{Mol} \% \\
\mathrm{G}+\mathrm{C}\end{array}$ & $\begin{array}{l}\text { Refer- } \\
\text { ence }\end{array}$ \\
\hline Actinomyces bovis (2 strains) & 63.0 & 6 \\
\hline Arachnia propionica (10 strains) & $64.0-65.0$ & 6 \\
\hline Nocardia asteroides & 66.0 & 7 \\
\hline N. asteroides (2 strains) & $67.0-68.0$ & 1 \\
\hline N. erythropolis . . . . . & $62.0-63.0$ & 1 \\
\hline$N$. corallina ( 3 strains) & $62.0-67.0$ & 1 \\
\hline N. madurae & 68.0 & 1 \\
\hline N. opeca & 63.0 & 1 \\
\hline N. rubra & 66.0 & 1 \\
\hline N. brasiliensis & 65.0 & 7 \\
\hline $\begin{array}{l}\text { Rothia dentocariosa (10 strains; } \\
\text { filamentous) } \ldots \ldots \ldots \ldots \ldots \ldots\end{array}$ & $65.4-69.7$ & 5 \\
\hline $\begin{array}{l}\text { Rothia dentocariosa (1 strain; } \\
\text { coccal) } \ldots \ldots \ldots \ldots \ldots \ldots\end{array}$ & 68.0 & 5 \\
\hline Bacterionema matruchotii. & $55.0-58.0$ & \\
\hline
\end{tabular}

filamentous species of the family Actinomycetaceae. All species of the family Actinomycetaceae show $\mathrm{G}+\mathrm{C}$ values between 62.0 and 69.7, significantly higher than those found for $B$. matruchotii strains. Although the precise taxonomic position of $B$. matruchotii will have to await further work, we feel that, on the basis of the present knowledge, the placement of the genus Bacterionema in the family Actinomycetaceae should be re-evaluated.

(A preliminary report of this research was presented at the 73rd Annual Meeting of the American Society for Microbiology 6-11 May 1973, Miami Beach, Fla. This paper is based on a portion of a thesis to be submitted by L.P. to the Graduate School, University of Maryland at Baltimore City, in partial fulfillment of the requirements for the Ph.D. degree in microbiology.)

\section{ACKNOWLEDGMENTS}

We are indebted to J. V. Osterman and B. T. Burlingham for many helpful discussions and advice. This work was supported in part by Public Health Service grant 5 T01 DE00088-12 from the National Institute of Dental Research, and by the Drew Endowment Fund of the University of Maryland.

\section{REPRINT REQUESTS}

Address reprint requests to: Dr. George N. Krywolap, Department of Microbiology, University of Maryland School of Dentistry, Baltimore, Md. 21201.

\section{LITERATURE CITED}

1. Bradley, S. G., G. H. Brownell, and J. Clark. 1973. Genetic homologies among nocardiae and other actinomycetes. Can. J. Microbiol. 19:10071014.

2. Dunny, G. M., T. Hausner, and D. B. Clewell. 1972. Buoyant densities of DNA from various strains of Streptococcus mutans. Arch. Oral Biol. 17:1001-1003.

3. Frontali, C., L. R. Hill, and L. G. Silvestri. 1965. The base composition of deoxyribonucleic acids of Streptomyces. J. Gen. Microbiol. 38:243-250.

4. Gilmour, M. N., A. Howell, Jr., and B. G. Bibby. 1961. The classification of organisms termed Leptotrichia (Leptothrix) buccalis. Bacteriol. Rev. 25:131-141.

5. Hammond, B. F. 1970. Deoxyribonucleic acid base composition of Rothia dentocariosa as determined by thermal denaturation. J. Bacteriol. 104:1024-1026.

6. Johnson, J. L., and C. S. Cummins. 1972. Cell wall composition and deoxyribonucleic acid similarities among the anaerobic coryneforms, classical propionibacteria and strains of Arachnia propionica. J. Bacteriol. 109:1047-1066. 
7. Jones, L. A., and S. G. Bradley. 1964. Phenetic classification of actinomycetes. Develop. Ind. Microbiol. 5:267-272.

8. Mandel, M., and J. Marmur. 1968. Use of ultraviolet absorbance-temperature profile for determining the guanine plus cytosine content of DNA, p. 195-206. In L. Grossman and K. Moldave (ed.), Methods in enzymology, vol. 12B. Academic Press Inc., New York.

9. Mandel, M., C. L. Schildkraut, and J. Marmur. 1968. Use of $\mathrm{CsCl}$ density gradient analysis for determining the guanine plus cytosine content of DNA, p. 184-195. In L. Grossman and K. Moldave (ed.), Methods in enzymology, vol. 12B. Academic Press Inc., New York.

10. Marmur, J., and P. Doty. 1962. Determination of the base composition of deoxyribonucleic acid from its thermal denaturation temperature. J. Mol. Biol. 5:109-118.

11. Page, L. R., J. V. Osterman, and G. N. Krywolap. 1973. A method for lysing Bacterionema matruchotii. J. Dent. Res. 52:1159.

12. Streckfuss, J. L., and W. N. Smith. 1970. Isolation of bacillary and streptococcal variants from Bacterionema matruchotii. J. Bacteriol. 104: 1399-1400. 